\title{
Pengembangan LKS Inkuiri Berbantuan Media PhET untuk Melatihkan Keterampilan Berpikir Kritis
}

\author{
Ismu Sukamto ${ }^{1}$, Hervin Maulina ${ }^{2}$ \\ ${ }^{1}$ Pendidikan Guru Sekolah Dasar, Universitas Lampung \\ ${ }^{2}$ Pendidikan Fisika, Universitas Lampung \\ Jl. Prof. Dr. Sumantri Brojonegoro No 1 Bandar Lampung \\ E-mail: ismu.sukamto1101@fkip.unila.ac.id
}

\begin{tabular}{l}
\hline Article Info \\
\hline Received Januari 2021 \\
Accepted April 2021 \\
Published April 2021 \\
\end{tabular}

Keywords:

Critical thinking skills, student worksheets, inquiry, PhET.

\begin{abstract}
This study aimed to develop a PhET-assisted Student Worksheet (LKS) in training students' critical thinking skills. This development uses a 3-D model (Define, Design, and Develop). The product development, which has been validated and revised, was then tested on 44 students of class XI public high school in Surabaya using the One Group Pretest-Posttest design. Based on the research data, it can be concluded that the PhETassisted inquiry worksheets on the supported gas kinetic theory teaching materials are declared valid in quality in training high school students' critical thinking skills with an increase in skills reaching $80 \%$.
\end{abstract}

\begin{abstract}
Abstrak : Penelitian ini bertujuan untuk mengembangkan Lembar Kerja Siswa (LKS) inkuiri berbantuan PhET dalam melatihkan keterampilan berpikir kritis siswa. Pengembangan ini menggunakan model 3-D (Define, Design, dan Develop). Produk pengembangan yang telah divalidasi dan direvisi, kemudian diujicobakan pada 44 siswa kelas XI SMA negeri di Kota Surabaya dengan menggunakan rancangan One Group Pretest-Posttest. Berdasarkan data hasil penelitian, maka dapat disimpulkan bahwa LKS inkuiri berbantuan PhET pada materi ajar teori kinetik gas yang didukung dinyatakan valid berkualitas dalam melatihkan keterampilan berpikir kritis siswa SMA dengan peningkatan keterampilan mencapai $80 \%$.
\end{abstract}

Kata Kunci: Keterampilan berpikir kritis, lembar kerja siswa, inkuiri, PhET.

C2021 Jurusan Ilmu Pendidikan, FKIP Universitas Lampung 


\section{PENDAHULUAN}

Keterampilan berpikir kritis menjadi salah satu kemampuan yang harus dikuasai untuk dapat menguasai Higher Order Thinking Skills (HOTS), yang secara tersirat tercantum dalam Kompetensi Inti (KI) dalam Kurikulum 2013, yaitu: memahami, menerapkan, dan menganalisis pengetahuan faktual, konseptual, prosedural, dan metakognitif. Dengan menguasai keterampilan berpikir kritis, siswa mampu memahami pengetahuan-pengetahuan faktual yang membentuk sebuah pengetahuan konseptual dan kemudian menerapkannya dalam kehidupan sehari-hari (Ramos et al., 2013). Ketika siswa tersebut menemukan masalah atau fenomena baru, maka akan lebih mudah untuk menganalisis dan menguraikan masalah tersebut berdasarkan pengetahuan yang sudah dipahami melalui prosedur ilmiah di mana pada setiap langkahnya siswa dilatih untuk berpikir kritis dalam menentukan setiap inti permasalahan dari langkah-langkah tersebut. Oleh karena itu, pendidik harus membelajarkan materi-materi fisika di mana tugas instruksional utamanya adalah menciptakan aktivitas-aktivitas atau lingkungan belajar yang membimbing siswa untuk belajar dengan melibatkan keterampilan berpikir tingkat tinggi, dimulai dari mengetahui, memahami, menerapkan, menganalisis, mengevaluasi dan menciptakan sesuatu berdasarkan tingkatantingkatan hirarki proses kognitif tersebut.

Mempertimbangkan keterampilan berpikir kritis sebagai indikator keberhasilan pembelajaran, maka perlu dikembangkan LKS. LKS ini dirancang untuk melibatkan siswa secara langsung ke dalam proses ilmiah dalam waktu yang relatif singkat. Pembelajaran dengan menggunakan LKS ini dapat meningkatkan pemahaman sains, produktif dalam berpikir kreatif dan siswa menjadi terampil dalam memperoleh dan menganalisis sendiri penemuannya dengan penuh percaya diri (Ahmadi et al., 2011). Dengan demikian, aktivitas inkuiri siswa tidak hanya mengembangkan kemampuan intelektual tetapi juga seluruh potensi yang ada dan melatihkan keterampilan berpikir kritis dalam rangka mencapai HOTS. Selain itu, LKS meminimalisir peran guru dalam pembelajaran sehingga siswa dapat benar-benar bereksplorasi sesuai dengan karateristik siswa. Meskipun demikian, bimbingan guru tetap masih diperlukan 
agar aktivitas kognitif tersebut dapat menghasilkan pembentukan pengetahuan yang bermakna (Mayer, 2004).

Satu hal yang memiliki potensi untuk meningkatkan perkembangan HOTS dalam penggunaan LKS adalah media percobaan virtual interaktif. Media virtual interaktif memungkinkan siswa untuk mengakui materi yang ada di dalamnya ketika komputer menampilkan perhitungan, penyimpanan dan pengulangan informasi. Pengulangan yang dilakukan dengan proses mengembangkan hipotesis, mengubah variabel-variabel dan mengamati hasilnya, mengumpulkan data, mengatur kembali nilai setiap variabel, kemudian menjalankan simulasi untuk menguji hipotesis yang sudah dibuat akan meningkatkan pemahaman konsep pada materi tersebut (Jimoyiannis \& Komis, 2001). Keuntungan lainnya adalah siswa juga dapat melengkapi eksperimen yang terlalu sulit atau terlalu berbahaya untuk dilakukan di dalam kelas atau membutuhkan waktu yang lama (Sahin, 2006). Ini menunjukkan bahwa selain dapat meningkatkan efektivitas pembelajaran, simulasi juga dapat lebih mengefisiensikan waktu pembelajaran. Hasil penelitian terdahulu juga menyatakan bahwa dari 3 kelompok mahasiswa yang melakukan pembelajaran, yaitu: kelompok yang menggunakan laboratorium nyata kelompok yang menggunakan simulasi komputer, dan kelompok yang sama sekali tidak menggunakan laboratorium, kelompok yang menggunakan simulasi komputer memiliki pemahaman konseptual yang lebih unggul(Finkelstein et al., 2005).

Seiring dengan perkembangan Teknologi Informasi dan Komunikasi (TIK), banyak simulasi-simulasi fisika yang bisa diunduh secara gratis melalui media internet. Namun, tidak semua simulasi tersebut mampu menghadirkan konsep fisika yang benar atau standar sebagai media pembelajaran yang valid. Satu yang tepat digunakan sebagai standar media pembelajaran adalah $\mathrm{PhET}$ (Physics Education Technology). Simulasi-simulasi PhET merupakan gambar bergerak (animasi), interaktif dan dibuat seperti layaknya permainan di mana siswa dapat belajar dengan melakukan eksplorasi. Simulasi-simulasi tersebut menekankan korespondensi antara fenomena nyata dan simulasi komputer yang disajikan dalam model-model konseptual fisis yang mudah dimengerti oleh para siswa. Dengan demikian, objek-objek yang tidak terlihat oleh mata di dunia nyata akan mudah diamati sehingga siswa dapat menyelidiki sebab dan 
akibat dari fenomena yang disajikan. Penerapan PhET dalam pembelajaran terbukti efektif dalam mengembangkan keterampilan proses sains siswa dan menuntaskan hasil belajar psikomotor (Prihatiningtyas et al., 2013).

Berdasarkan uraian yang telah dikemukakan, maka perlu dikembangkan perangkat pembelajaran inkuiri berbantuan PhET Interactive Simulations untuk melatihkan keterampilan berpikir kritis siswa. Dengan demikian, maka pertanyaan penelitian yang dikembangkan adalah sebagai berikut.

1. Bagaimanakah validitas LKS inkuiri berbantuan PhET pada materi ajar teori kinetik gas?

2. Bagaimanakah keterampilan berpikir kritis siswa setelah diajarkan materi ajar teori kinetik gas dengan menerapkan LKS inkuiri berbantuan PhET?

3. Bagaimanakah respons siswa setelah diajarkan materi ajar teori kinetik gas dengan menerapkan LKS inkuiri berbantuan PhET?

\section{METODE}

\section{Jenis Penelitian}

Penelitian ini merupakan penelitian pengembangan dengan produk pengembangan berupa LKS inkuri berbantuan PhET. LKS tersebut diujicobakan pada 44 siswa Kelas XI Program Ilmu Pengetahuan Alam (IPA) pada salah satu SMA negeri di Kota Surabaya, yang terbagi pada Kelas XI IPA 2 sebanyak 23 orang dan Kelas XI IPA 5 sebanyak 21 orang.

\section{Kriteria LKS Inkuri Berbantuan PhET}

LKS yang dikembangkan sebanyak 3 buah yang disusun secara komprehensif untuk menguasi materi Teori Kinetik Gas. Setiap LKS tersusun atas 9 bagian utama, yaitu: (1) Indikator Pembelajaran; (2) Pengantar; (3) Rumusan Masalah; (4) Hipotesis; (5) Variabel Percobaan; (6) Definisi Operasional Variabel Percobaan; (7) Prosedur dan Data Hasil Percobaan Berbantuan PhET; (8) Analisis Hasil Percobaan; dan (9) Pemanfaatan Ilmu. Indikator pembelajaran adalah capaian yang perlu diraih oleh siswa setelah proses pembelajaran dengan menggunakan LKS. Pengantar adalah teks berisi fenomena sehari-hari yang berkaitan dengan percobaan dan mengarahkan 
mahasiswa untuk merumuskan masalah sebagai dasar melakukan percobaan. Rumusan masalah adalah pertanyaan yang perlu djawab berdasarkan percobaan yang akan dilakukan. Siswa menentukan sendiri rumusan masalah berdasarkan indicator dan pengantar yang telah disajikan. Berdasarkan masalah yang dirumuskan, mahasiswa berhipotesis. Variabel dan definisi operasional variable didefinisikan oleh siswa agar memahami apa yang perlu dilakukan selama percobaan. Dalam kasus ini, tidak dinyatakan alat dan bahan karena sudah digantikan dengan PhET sehingga siswa hanya perlu melakukan percobaan sesuai prosedur dan menuliskan hasil pengamatan. Berdasarkan data hasil pengamatan, siswa menganalisis dengan panduan pertanyaanpertanyaan yang telah disediakan yang mengarah pada satu kesimpulan. Terakhir, siswa mengerjakan soal yang merupakan penerapan dari pengetahuan konseptual yang sudah didapatkan dari percobaan.

\section{Prosedur Penelitian}

Prosedur ini menerapkan model pengembangan 3-D yang diadaptasi dari model 4-D (Thiagarajan, 1974). Ketiga tahapan 3-D tersebut adalah Define (Pendefinisian), Design (Perancangan), dan Develop (Pengembangan). Model 3D disajikan pada Gambar 1. 


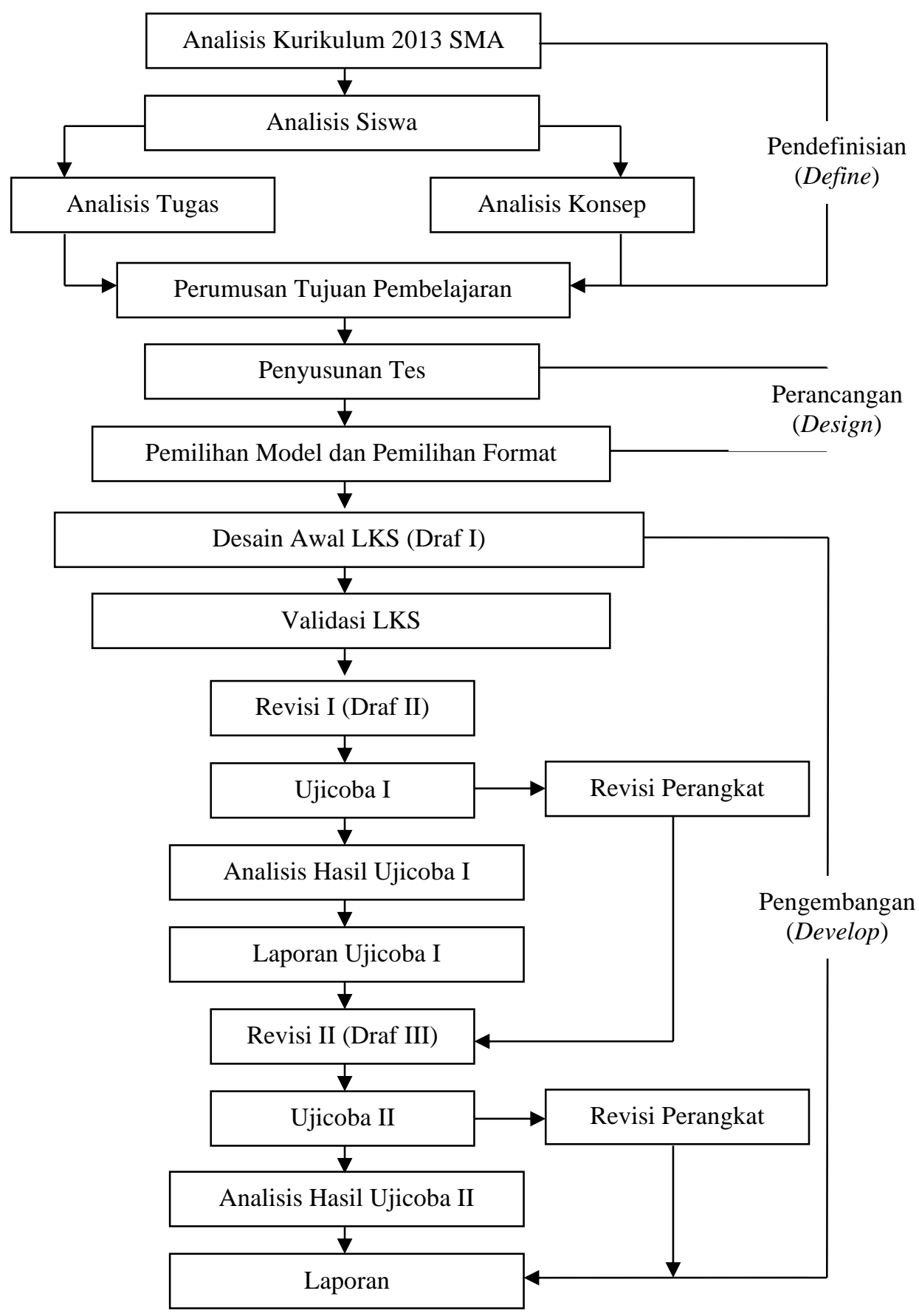

Gambar 1. Diagram Alir Rancangan Pengembangan 3-D

\section{Instrumen dan Teknik Pengumpulan Data}

\section{Validasi Ahli}

Instrumen yang digunakan dalam penelitian ini adalah lembar validasi yang ditujukan untuk menentukan kualitas kelayakan dan penyempurnaan sebelum diujicobakan. Instrumen ini tersusun atas 3 aspek, yaitu: (1) penyajian, (2) bahasa dan keterbacaan; dan (3) kesesuaian dengan pembelajaran inkuiri. 
Validasi dilakukan oleh 2 pakar yang ahli dalam bidang pendidikan dengan memberikan skor penilaian dan saran perbaikan untuk kesempurnaan LKS.

\section{Tes Keterampilan Berpikir Kritis}

Tes ini difokuskan pada ketuntasan individu siswa dalam pembelajaran yang terdiri atas 12 butir soal uraian (C4 - C5) dengan 6 indikator yang diadaptasi dari FRISCO (Ennis, 2015), yaitu (1) merumuskan masalah; (2) membuat argumen; (3) melakukan deduksi; (4) melakukan induksi; (5) melakukan evaluasi; dan (6) memutuskan dan melaksanakan. Tes ini kemudian diujikan sebagai pre-test dan post-test. Dengan berdasarkan pada data hasil pre-test dan post-test yang telah dianalisis secara deskriptif tersebut, efektivitas LKS dapat ditentukan (n-gain score). Selain itu, berdasarkan hasil uji statistic, instrument tes dinyatakan valid dengan perolehan skor per butir soal antara 3,50 - 4,00 (skala 1-4) dan reliabel dengan persentase 94\%.

\section{Respons Siswa}

Instrumen yang digunakan adalah angket respons siswa yang tersusun atas 5 indikator penilaian, yaitu: (1) Kesenangan dalam penggunaan; (2) Kebaruan; (3) Kelanjutan penggunaan; (4) Kemudahan; dan (5) Kemenarikan. Setiap indikator dalam lembar angket respons siswa berisikan perihal yang berkaitan dengan pembelajaran yang diberikan yang disertai dua pilihan jawaban untuk siswa pilih berdasarkan penilaiannya terhadap pembelajaran tersebut. Pada pilihan jawaban tersebut, terdapat skor yang mewakili penilaian siswa dengan ketentuan "Ya" bernilai 1 dan "Tidak" bernilai 0 .

\section{Teknik Analisis Data}

\section{Analisis Hasil Validasi LKS}

Setiap komponen penilaian pada lembar validasi perangkat pembelajaran disajikan 4 kotak pilihan dengan skor penilaian dari 1 sampai dengan 4 . Komponen-komponen penilaian tersebut dinilai dengan memberikan tanda checklist $(\sqrt{ })$ pada kolom penilaian dengan aturan: 4 untuk kriteria "baik/layak/valid", 3 untuk kriteria "cukup baik/layak/valid", 2 untuk kriteria "kurang baik/layak/valid, dan 1 untuk kriteria "tidak baik/layak/valid". Teknik analisis data pada aspek yang dinilai adalah secara deskriptif kualitatif berdasarkan nilai rata-rata penilaian para pakar dengan kriteria penilaian sebagai berikut.

Tabel 1. Kriteria kelayakan

\begin{tabular}{cc}
\hline Rentang Skor & Kriteria \\
\hline $1,00-1,49$ & Tidak layak/baik/valid \\
$1,50-2,49$ & Kurang layak/baik/valid \\
$2,50-2,99$ & Cukup layak/baik/valid \\
$3,00-4,00$ & Layak/baik/valid \\
\hline
\end{tabular}




\section{Analisis Hasil Belajar Keterampilan Berpikir Kritis}

Skor keterampilan berpikir kritis siswa diperoleh berdasarkan data hasil pre-test dan post-test, yang kemudian dianalisis secara deskriptif kualitatif. Skor keterampilan berpikir kritis siswa memiliki karakteristik rentang skor antara $0-85$. Skor tersebut dikonversi ke dalam rentang persentase $0 \%-$ 100\%. Pengkonversian dilakukan pada skor pre-test dan post-test. Deskripsi umum nilai rata-rata keterampilan berpikir kritis selanjutnya diberikan predikat secara kualitatif untuk setiap rentang nilai tertentu. Pedoman kriteria skor nilai tersebut tercantum pada Tabel 2.

Tabel 2. Kriteria Skor Penilaian Keterampilan Berpikir Kritis

\begin{tabular}{ccc}
\hline Skor & \multicolumn{2}{c}{ Keterampilan Berpikir Kritis } \\
& Proporsi (\%) & Kategori \\
\hline $77-85$ & $91-100$ & Sangat baik \\
$64-76$ & $75-90$ & Baik \\
$55-63$ & $65-74$ & Cukup baik \\
$<55$ & $<65$ & Kurang baik \\
\hline
\end{tabular}

Data dianalisis untuk mengetahui peningkatan keterampilan berpikir kritis sebelum dan sesudah pembelajaran diberikan, dengan menggunakan perumusan gain skor sebagai berikut:

Keterangan:

$$
g=\frac{S_{\text {post }}-S_{\text {pre }}}{100 \%-S_{\text {pre }}}
$$

$g \quad=$ peningkatan keterampilan berpikir kritis siswa

$S_{\text {pre }} \quad=$ rata-rata keterampilan berpikir kritis siswa pada pretest $(\%)$

$S_{\text {post }} \quad=$ rata-rata keterampilan berpikir kritis siswa pada posttest $(\%)$

Selanjutnya, hasil perhitungan dikonversi dengan mengacu pada kriteria sebagai berikut (Hake, 1999).

Tabel 3. Kriteria Normalized Gain

\begin{tabular}{cc}
\hline Skor $\boldsymbol{N}$-Gain & Kriteria Normalized Gain \\
\hline $0,70<N$-Gain & Tinggi \\
$0,30 \leq N$-Gain $\leq 0,70$ & Sedang \\
$N$-Gain $<0,30$ & Rendah \\
\hline
\end{tabular}

\section{Analisis Respons Siswa}

Analisis data respons siswa mengikuti proses pembelajaran dengan menggunakan LKS yang dilakukan secara deskriptif kualitatif, yaitu dengan mempresentasekan respon positif dan negatif siswa dalam mengisi lembar angket respons siswa untuk memperoleh data mengenai pendapat dan komentar tentang LKS yang dikembangkan peneliti sesuai dengan pembelajaran inkuiri berbantuan PhET. Untuk menghitung persentase jawaban siswa, dilakukan dengan menghitung proporsi jawaban yang ada dibagi dengan jumlah siswa yang menerima angket dikalikan $100 \%$. 
Data respons siswa diperoleh dari angket respons siswa terhadap kegiatan pembelajaran. Respons siswa dianalisis secara deskriptif kuantitatif dengan presentase yang diperoleh menggunakan rumus sebagai berikut (Borich, 1994).

Keterangan:

$$
P=\frac{\sum K}{\sum N} \times 100 \%
$$

$P \quad=$ Presentase

$\sum \mathrm{K} \quad=$ Jumlah jawaban respons

$\sum N=$ Jumlah respons

Dengan kriteria pendeskripsian disajikan pada Tabel 4 berikut ini.

Tabel 4. Kriteria Pendeskripsian Respons Siswa

\begin{tabular}{cc}
\hline Rentang Skor & Kriteria \\
\hline $0 \%-25 \%$ & Buruk \\
$26 \%-50 \%$ & Kurang Baik \\
$51 \%-75 \%$ & Cukup Baik \\
$76 \%-100 \%$ & Baik \\
\hline
\end{tabular}

\section{HASIL DAN PEMBAHASAN}

\section{Hasil}

\section{Validasi LKS}

Berdasarkan hasil validasi ahli, instrumen ini dikatakan valid dengan skor 3,95 (skala 1-4) dan reliabel dengan nilai reliabilitasnya 99\% (Borich, 1994) dengan rincian disajikan pada Tabel 5 berikut ini.

Tabel 5. Data Hasil Validasi LKS

\begin{tabular}{lcc}
\hline \multicolumn{1}{c}{ Aspek } & Rata-Rata Skor & Kategori Penilaian \\
\hline Penyajian & 4,00 & Layak \\
Bahasa dan Keterbacaan & 4,00 & Layak \\
Kesesuain dengan Pembelajaran & 3,84 & Layak \\
Inkuiri & & \\
\hline
\end{tabular}

Pada tahap validasi, beberapa perbaikan yang dilakukan adalah menyederhanakan kunci jawaban soal pada bagian pemanfaatan ilmu yang terdapat LKS 2. Saran perbaikan tersebut dijadikan dasar dalam menyempurnakan LKS. Tabel 6 menyajikan rangkuman saran validator. 
Tabel 6. Data Rangkuman Aspek dan Saran Perbaikan LKS

\begin{tabular}{|c|c|}
\hline Aspek Perbaikan & Saran Perbaikan \\
\hline $\begin{array}{l}\text { Ketika Anda menarik napas, otot-otot } \\
\text { mengembangkan dinding dada Anda dan menarik } \\
\text { diafragma (otot besar di bawah dada) ke bawah, } \\
\text { membiarkan paru-paru yang elastik (tanpa pengunaan } \\
\text { otot) untuk mengembang (lihat Gambar Inspirasi). } \\
\text { Paru-paru yang mengembang (volume udara } \\
\text { bertambah) menyebabkan tekanan di dalam paru-paru } \\
\text { di bawah tekanan atmosfer. Tekanan dalam paru-paru } \\
\text { yang lebih kecil daripada tekanan atmosfer (tekanan } \\
\text { udara luar) meyebabkan udara dari luar memasuki } \\
\text { paru-paru. Ketika otot relaks, jaringan paru-paru yang } \\
\text { tadinya kencang karena ditarik diafragma juga ikut } \\
\text { relaks. Diafragma bergerak ke atas dan paru-paru } \\
\text { mengempis (kembali tanpa penggunaan otot, lihat } \\
\text { Gambar Ekspirasi). Paru-paru mengempis menaikkan } \\
\text { tekanan udara dalam paru-paru sehingga udara dari } \\
\text { paru-paru keluar. }\end{array}$ & $\begin{array}{l}\text { Paru-paru yang mengembang } \\
\text { (volume udara bertambah) } \\
\text { menyebabkan tekanan di } \\
\text { dalam paru-paru di bawah } \\
\text { tekanan atmosfer. Tekanan } \\
\text { dalam paru-paru yang lebih } \\
\text { kecil daripada tekanan } \\
\text { atmosfer (tekanan udara luar) } \\
\text { meyebabkan udara dari luar } \\
\text { memasuki paru-paru. Ketika } \\
\text { otot relaks, diafragma } \\
\text { bergerak ke atas dan paru- } \\
\text { paru mengempis. Paru-paru } \\
\text { mengempis menaikkan } \\
\text { tekanan udara dalam paru- } \\
\text { paru sehingga udara dari } \\
\text { paru-paru keluar. }\end{array}$ \\
\hline
\end{tabular}

Berikut ini adalah tampilan LKS inkuri berbantuan PhET untuk melatihkan keterampilan berpikir kritis siswa.

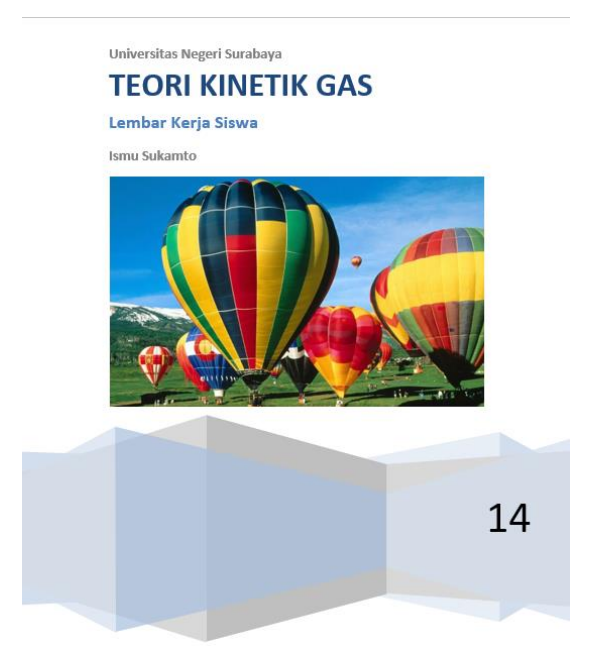

(a)

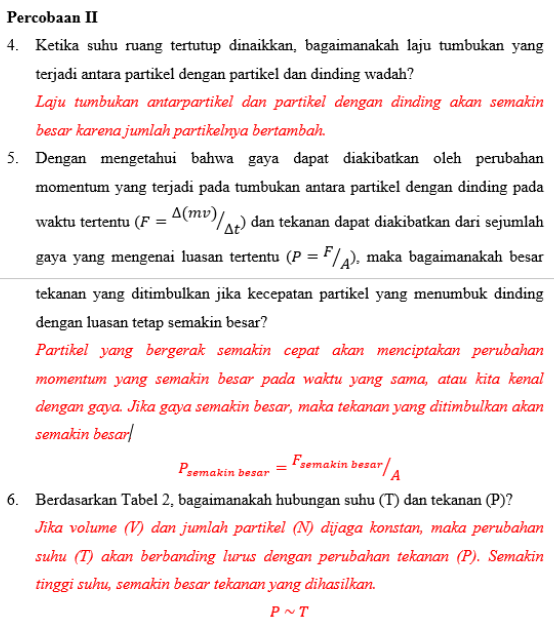

(b)

Gambar 2. (a) Sampul LKS Inkuri II; (b) Bagian Analisis Hasil Percobaan pada LKS Inkuiri I 


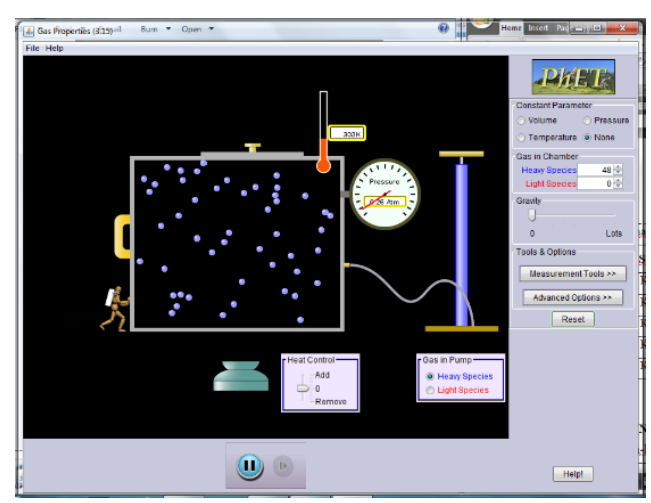

Gambar 3. PhET Simulations

\section{Keterampilan Berpikir Kritis}

Berdasarkan data hasil penelitian, keterampilan berpikir kritis siswa dapat disajikan sebagai berikut.

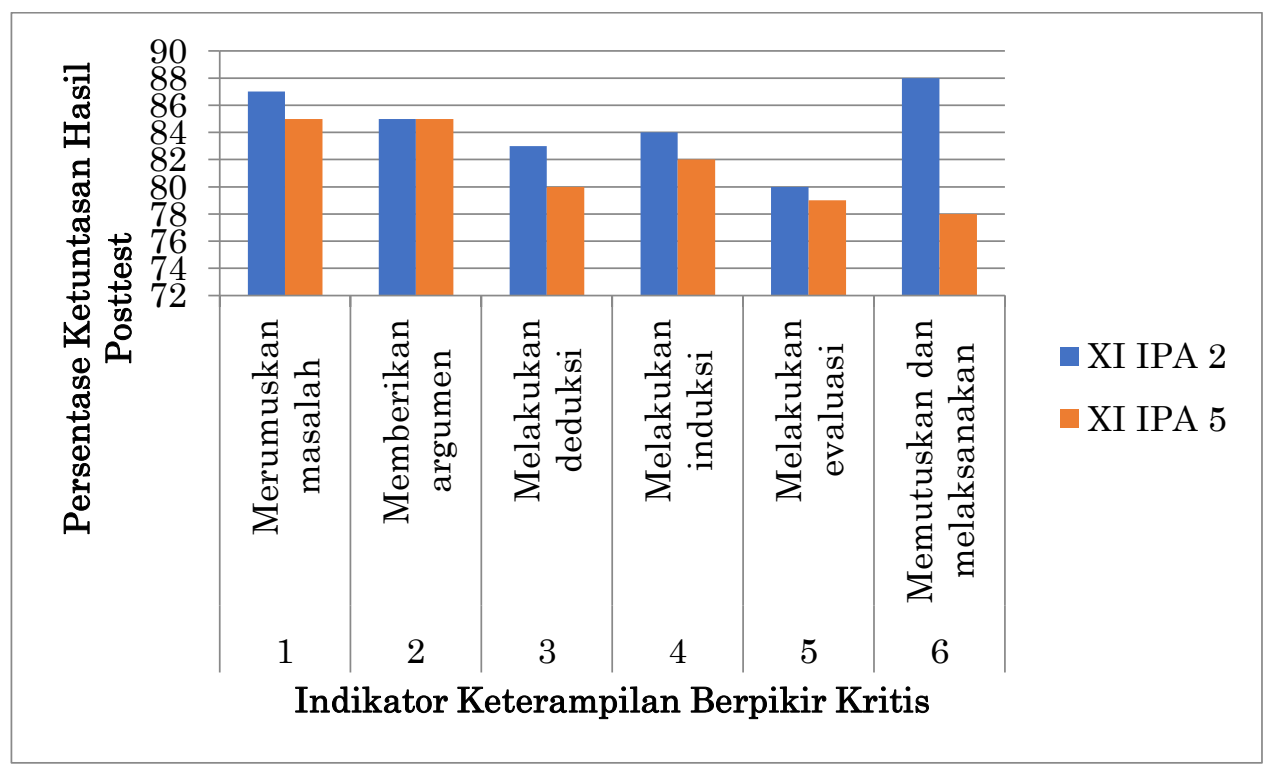

Gambar 4. Perbandingan Persentase Ketuntasan Indikator Keterampilan Berpikir Kritis pada Kelas XI IPA 2 dan Kelas XI IPA 5

Berdasarkan data pada Gambar 5, secara keseluruhan persentase ketuntasan indikator keterampilan berpikir kritis pada kelas XI IPA 2 lebih tinggi dibandingkan dengan kelas XI IPA 5 dan konsisten dengan perbedaan persentase yang tidak terlalu tinggi. Hal ini terlihat dari persentase pada setiap indikator. Meskipun demikian, ada 1 indikator pembelajaran yang memiliki nilai yang sama di antara kedua kelas tersebut, yaitu indikator ke-2; dan terdapat juga 1 indikator yang memiliki perbedaan yang cukup tinggi, yaitu pada indikator ke-6 dengan selisih sebesar $10 \%$. 
Sementara itu, perhitungan Gain-Score (skor peningkatan) secara detail yang diperoleh dari hasil prestet dan post-test dapat dilihat pada Tabel 7 berikut ini.

Tabel 7. Gain-Score Keterampilan Berpikir Kritis Siswa

\begin{tabular}{cccc}
\hline No & Kode Siswa & N-Gain & Keterangan \\
& & & Tinggi \\
\hline 1 & Kelas XI IPA 2 & 0,82 & Tinggi \\
\hline
\end{tabular}

Secara keseluruhan, gain-score pada kedua kelas tidak jauh berbeda dan memiliki kategori yang sama, yaitu tinggi. Meskipun demikian, Kelas XI IPA 2 memiliki gain-score lebih tinggi dibandingkan Kelas XI IPA 5.

\section{Respons Siswa}

Tabel 8 menyajikan rangkuman hasil respons siswa terhadap pembelajaran yang diterapkan.

Tabel 8. Rangkuman Hasil Respons Siswa terhadap Pembelajaran

\begin{tabular}{|c|c|c|c|c|c|c|c|}
\hline \multirow{2}{*}{ No } & \multirow{2}{*}{$\begin{array}{c}\text { Aspek } \\
\text { Penilaian }\end{array}$} & \multicolumn{4}{|c|}{ Persentase Nilai Rata-Rata Kriteria } & \multirow{2}{*}{$\begin{array}{l}\text { Rata- }^{-} \\
\text {rata }\end{array}$} & \multirow{2}{*}{ Kate-gori } \\
\hline & & \multicolumn{2}{|c|}{ Kelas XI IPA 2} & \multicolumn{2}{|c|}{ Kelas XI IPA 5} & & \\
\hline \multirow[t]{2}{*}{1} & \multirow{2}{*}{$\begin{array}{l}\text { Kesenangan } \\
\text { dalam } \\
\text { Penggunaan } \\
\text { Perangkat }\end{array}$} & Senang & Tidak & Senang & Tidak & \multirow[b]{2}{*}{$91 \%$} & \multirow[b]{2}{*}{ Senang } \\
\hline & & $93 \%$ & $7 \%$ & $89 \%$ & $11 \%$ & & \\
\hline \multirow[t]{2}{*}{2} & \multirow{2}{*}{$\begin{array}{l}\text { Kebaruan } \\
\text { Perangkat }\end{array}$} & Baru & Tidak & Baru & Tidak & \multirow[b]{2}{*}{$84 \%$} & \multirow[b]{2}{*}{ Baru } \\
\hline & & $89 \%$ & $11 \%$ & $78 \%$ & $22 \%$ & & \\
\hline \multirow[t]{2}{*}{3} & \multirow{2}{*}{$\begin{array}{l}\text { Kelanjutan } \\
\text { Penggunaan } \\
\text { Perangkat }\end{array}$} & Lanjut & Tidak & Lanjut & Tidak & \multirow{2}{*}{$89 \%$} & \multirow{2}{*}{ Lanjut } \\
\hline & & $96 \%$ & $4 \%$ & $81 \%$ & $19 \%$ & & \\
\hline \multirow[t]{2}{*}{4} & \multirow{2}{*}{$\begin{array}{l}\text { Kemudahan } \\
\text { Perangkat }\end{array}$} & Mudah & Tidak & Mudah & Tidak & \multirow{2}{*}{$91 \%$} & \multirow{2}{*}{ Mudah } \\
\hline & & $94 \%$ & $6 \%$ & $87 \%$ & $13 \%$ & & \\
\hline \multirow[t]{2}{*}{5} & \multirow{2}{*}{$\begin{array}{l}\text { Kemenarikan } \\
\text { Perangkat }\end{array}$} & Menarik & Tidak & Menarik & Tidak & \multirow{2}{*}{$91 \%$} & \multirow{2}{*}{ Menarik } \\
\hline & & $90 \%$ & $10 \%$ & $92 \%$ & $8 \%$ & & \\
\hline
\end{tabular}

Berdasarkan data pada Tabel 8, dapat disimpulkan bahwa LKS menyenangkan dengan persentase sebesar 91\%, tergolong baru dengan persentase $84 \%$, diharapkan dapat digunakan pada materi ajar berikutnya dengan persentase 89\%, mudah digunakan dengan persentase 91\%, dan menarik ketika digunakan dalam pembelajaran dengan persentase sebesar $91 \%$. 


\section{Pembahasan}

\section{Validasi LKS}

Lembar Kerja Siswa (LKS) dikembangkan untuk memandu siswa dalam menggali pengetahuan yang harus dikuasai sesuai dengan tujuan pembelajaran secara mandiri (Nur, 2008). LKS juga dikembangkan untuk melatihkan keterampilan berpikir kritis siswa pada setiap prosedur ilmiah di dalam LKS yang meliputi menganalisis fenomena yang diberikan, merumuskan masalah berdasarkan fenomena dan tujuan percobaan, merumuskan hipotesis, menentukan variabel, mengumpulkan data percobaan, menganalisis data hasil percobaan, menyimpulkan hasil percobaan dan menerapkan konsep-konsep yang didapatkan untuk menjelaskan fenomena-fenomena dalam kehidupan sehari-hari. Sesuai dengan jumlah pertemuan yang telah ditetapkan, LKS juga dikembangkan sebanyak 3 buah. Selain berfungsi sebagai panduan kegiatan, setiap LKS juga berfungsi untuk meminimalisir keterlibatan guru dalam pembelajaran (teacher-centered) sehingga siswa lebih aktif secara kognitif dan mendominasi seluruh kegiatan pembelajaran inkuiri (student-centered) (Mayer, 2004).

LKS yang sudah disusun kemudian divalidasi oleh 2 orang ahli untuk mengetahui tingkat kelayakan LKS untuk membelajarkan materi ajar teori kinetik gas dalam melatihkan keterampilan berpikir kritis. Proses validasi juga dimaksudkan untuk menyempurnakan LKS berdasarkan pengetahuan dan pengalaman dari para validator selama berkecimpung dalam dunia pendidikan melalui saran perbaikan yang meliputi penyederhanaan kunci jawaban soal pada bagian pemanfaatan ilmu yang terdapat LKS 2 .

Dengan menganalisis dan mendeskripsikan data hasil validasi, dapat dinyatakan bahwa komponen-komponen LKS yang meliputi penyajian, bahasa dan keterbacaan, dan kesesuaian dengan pembelajaran inkuiri dinyatakan layak untuk sebagai komponen utama LKS dalam melatihkan keterampilan berpikir kritis. Dengan demikian, dapat disimpulkan bahwa LKS layak untuk digunakan sebagai panduan dalam melatihkan keterampilan berpikir kritis dengan tingkat kepercayaan tinggi yang dibuktikan dengan nilai reliabilitas nilai lebih besar dari 75\%, yang artinya instrumen yang digunakan untuk memvalidasi reliabel atau dapat dipercaya keabsahannya (Borich, 1994). 
Peningkatan keterampilan berpikir kritis juga didukung dengan penggunaan PhET Simulations. Perlu diingat lagi bahwa setiap materi pembelajaran idealnya akan mudah dipahami jika dalam membelajarkannya dengan menyediakan pengalaman langsung yang berkaitan dengan materi tersebut (Arsyad, 2011). Meskipun demikian, tidak semua pengalaman langsung dapat diberikan dalam pembelajaran di kelas dengan pemanfaatan waktu yang efektif dan efiesien. Pertimbangan lainnya adalah tidak semua materi ajar dapat diajarkan dengan pengalaman langsung karena konsepkonsep yang tergolong abstrak dan hampir tidak mungkin untuk mengamatinya dalam kehidupan sehari-hari. Oleh karena itu, sesuai dengan pertimbanganpertimbangan tersebut dan Kerucut Pengalaman Dale (Arsyad, 2011), dalam mengajarkan materi teori kinetik gas yang merupakan materi abstrak perlu adanya media yang mampu menggambarkan karakteristik partikel-partikel penyusun gas. Media yang tepat untuk digunakan adalah PhET. Dengan menggunakan media PhET, siswa tidak hanya dapat mengidentifikasi karakteristik dari partikel penysusun gas, tetapi juga dapat mempelajari akibat perilaku-perilaku partikel tersebut yang dipengaruhi suhu dan berakibat pada tekanan dan volumenya. Uraian tersebut merupakan penjelasan logis mengapa dalam penelitian ini keterampilan berpikir kritis siswa meningkat setelah diberi pembelajaran berbantuan PhET.

Sejumlah penelitianpun menunjukkan bahwa penerapan simulasi virtual berbasis penemuan mampu meningkatkan melatih keterampilan berpikir kritis, di antaranya: penelitian yang dilakukan oleh Liao yang menyimpulkan bahwa Computer Simulation Instruction (CSI) memiliki lebih banyak efek positif terhadap hasil belajar siswa dibandingkan dengan Traditional Instruction (TI) (Liao \& Chen, 2007), Eskrootchi menunjukkan bahwa siswa yang berpartisipasi dalam memanipulasi model eksperimental tentang eksperimen watershed dan the STELLA ( $A$ Study of the Efficacy of Project-based Learning Integrated with Computer- based Simulation) simulation memperlihatkan kinerja yang paling baik dalam memahami konsep watershed (Eskrootchi \& Oskrochi, 2010). 


\section{Keterampilan Berpikir Kritis Siswa}

Setelah melalui pembelajaran dengan menggunakan LKS inkuiri, keterampilan berpikir kritis siswa meningkat. Peningkatan tersebut diperkuat dengan mempertimbangkan tingkat capaian (gain score) yang tinggi, sehingga dapat dinyatakan bahwa peningkatan hasil belajar tersebut signifikan antara data hasil pretest dan posttest. Hal ini terjadi karena dengan menerapkan LKS, siswa didorong untuk terlibat aktif secara maksimal untuk mencari dan menyelidiki konsep-konsep yang ada pada materi ajar teori kinetik gas secara sistematis, kritis, logis dan analitis sehingga mereka dapat merumuskan sendiri penemuannya (Ahmadi et al., 2011). Dengan demikian, pengetahuanpengetahuan baru yang siswa temukan benar-benar bermakna dan tertanam dalam ingatan siswa yang menjadi bekal untuk menjelaskan fenomenafenomena yang diberikan pada tes sesuai dengan teori belajar bermakna yang dicetuskan oleh Ausubel.

Penggunaan LKS memberikan kebebasan yang lebih besar dalam proses inkuiri siswa akan lebih aktif dalam berpikir. Hal tersebut juga akan membentuk keterampilan ilmiah dan kemandirian siswa karena proprosi tanggung jawab siswa lebih besar dalam menganalisis topik di setiap tahapan pembelajaran inkuiri (Ahmadi et al., 2011). Pernyataan tersebut diperkuat dengan hasil metaanalisis Mayer yang menyatakan bahwa siswa perlu diberikan kebebasan untuk aktif secara kognitif dalam membangun pemahaman tetapi bimbingan guru tetap masih diperlukan agar aktivitas kognitif mereka dapat menghasilkan pembentukan pengetahuan yang bermakna (Mayer, 2004).

Perkembangan kemampuan berpikir sebagian juga bergantung pada sejauh mana siswa berinteraksi aktif antarsesama maupun dengan lingkungan. Siswa dalam setiap kelompok belajar diharapkan saling interaksi di antara anggota kelompok untuk melakukan kerjasama dalam menyelesaikan masalah-masalah pada setiap tahapan inkuiri. Dengan demikian, dalam interaksi tersebut terjadi transfer pengetahuan dari siswa yang lebih unggul dalam menemukan pengetahuan kepada siswa yang lebih unggul dalam bersosialisasi sehingga terjadi pemerataan pengetahuan dalam kelompok belajar tersebut. Sesuai dengan Teori Vygotsky, interaksi tersebut memungkinkan siswa untuk saling berkomunikasi aktif dan produktif dalam berbagi pengetahuan sehingga 
pengetahuan dan pengalaman pada masing-masing anggota akan saling melengkapi untuk semua anggota kelompok. Hal ini sesuai dengan teori perkembangan Piaget yang memandang perkembangan kognitif sebagai suatu proses di mana siswa secara aktif membangun sistem makna dan pemahaman realitas melalui pengalaman-pengalaman dan interaksi-interaksi mereka.

\section{Respons Siswa}

Berdasarkan persentase pada setiap aspek tersebut, dapat disimpulkan bahwa LKS menyenangkan ketika digunakan dalam pembelajaran dan tergolong baru dalam pembelajaran yang diterapkan di kelas. Selain itu, LKS juga mudah untuk digunakan dalam mendukung pembelajaran inkuiri dan menarik sehingga siswa tidak cepat merasa bosan ketika melakukan aktivitas inkuiri. Oleh karena itu, siswa-siswi memutuskan untuk dapat menggunakan LKS tersebut dalam pembelajaran pada materi ajar lainnya.

Namun, perlu dipertimbangkan lagi bahwa meskipun persentase penilaian pada setiap aspek respons siswa sudah berkriteria baik, beberapa aspek memiliki kelemahan yang perlu diperhatikan, yaitu: pada aspek kebaruan perangkat dan pada aspek kelanjutan penggunaan LKS. LKS yang dikembangkan sebenarnya merupakan hal baru bagi siswa, akantetapi siswa menilai LKS tersebut secara umum identik dengan soal-soal yang harus diselesaikan sehingga persepsi tersebut membuat LKS yang secara prosedural merupakan hal baru menjadi sesuatu yang biasa seperti pada umumnya. Penilaian siswa tentang LKS tersebut mempengaruhi penilaian terhadap tingkat kelanjutan penggunaan LKS dalam pembelajaran.

Respons siswa kemudian dijadikan pertimbangan untuk mengevaluasi kegiatan pembelajaran yang telah dilakukan karena tujuan pembelajaran adalah memfasilitasi siswa untuk menguasai kompetensi-kompetensi yang telah tercantum dalam kurikulum. Peneliti juga perlu memperhatikan setiap sikap dan tindakan yang tercermin pada siswa ketika melakukan pembelajaran. Hal ini perlu dilakukan karena mempertimbangkan setiap periode pendidikan karekateristik siswa selalu berubah dan perubahan ini harus diikuti dengan peningkatan model pembelajaran yang sesuai. Baik atau buruknya respons siswa terhadap pembelajaran tetap menjadi masukan yang berarti untuk peningkatan kualitas pembelajaran. Jika respons siswa baik, ini dapat menjadi 
sebuah keunggulan untuk dapat digunakan sebagai pertimbangan untuk menggunakan model pembelajaran ini pada materi ajar yang lain karena kenyamanan siswa mampu meningkatkan daya tangkap terhadap materi yang sedang diajarkan. Sebaliknya, jika respons siswa buruk, ini dapat dijadikan sebagai dasar untuk memperbaiki komponen-komponen dalam pembelajaran yang membuat siswa merasa tidak nyaman sehingga dapat ditemukan model terbaik dari suatu pembelajaran.

\section{KESIMPULAN}

Berdasarkan hasil dan pembahasan, maka dapat disimpulkan bahwa LKS inkuiri berbantuan PhET dinyatakan valid berkualitas dalam melatihkan keterampilan berpikir kritis siswa SMA dengan peningkatan keterampilan yang tinggi sebesar $80 \%$.

\section{DAFTAR PUSTAKA}

Ahmadi, I. K., Amri, S., Setyono, H. A., \& Elisah, T. (2011). Strategi pembelajaran berorientasi KTSP. Jakarta: PT. Prestasi Pustakarya.

Arsyad, A. (2011). Media pembelajaran. Jakarta: PT Raja grafindo persada.

Borich, G. D. (1994). Observation skills for effective teaching. New York.

Ennis, R. H. (2015). Critical thinking: A streamlined conception. In The Palgrave handbook of critical thinking in higher education (pp. 31-47). Springer.

Eskrootchi, R., \& Oskrochi, G. R. (2010). A study of the efficacy of project-based learning integrated with computer-based simulation-STELLA. J. Educ. Technol. Soc., 13(1), 236-245.

Finkelstein, N. D., Perkins, K. K., Adams, W., Kohl, P., \& Podolefsky, N. (2005). Can computer simulations replace real equipment in undergraduate laboratories? AIP Conference Proceedings, 790(1), 101-104.

Hake, R. R. (1999). Analyzing change/gain scores. Indiana: Indiana University.

Jimoyiannis, A., \& Komis, V. (2001). Computer simulations in physics teaching and learning: a case study on students' understanding of trajectory motion. Computers \& Education, 36(2), 183-204.

Liao, Y., \& Chen, Y. (2007). The effect of computer simulation instruction on student learning: A meta-analysis of studies in Taiwan. Journal of Information Technology and Applications (資訊科技與應用期刊)，2(2)，6979.

Mayer, R. E. (2004). Should there be a three-strikes rule against pure discovery learning? American Psychologist, 59(1), 14.

Prihatiningtyas, S., Prastowo, T., \& Jatmiko, B. (2013). Imlementasi simulasi PhET dan KIT sederhana untuk mengajarkan keterampilan psikomotor siswa pada pokok bahasan alat optik. Jurnal Pendidikan IPA Indonesia, 2(1). 
Ramos, J. L. S., Dolipas, B. B., \& Villamor, B. B. (2013). Higher order thinking skills and academic performance in physics of college students: A regression analysis. International Journal of Innovative Interdisciplinary Research, 4(1), 48-60.

Sahin, S. (2006). Computer simulations in science education: Implications for Distance Education. Online Submission, 74).

Thiagarajan, S. (1974). Instructional development for training teachers of exceptional children: A sourcebook. 